\title{
ABL1/BCR Fusion Gene
}

National Cancer Institute

\section{Source}

National Cancer Institute. ABL1/BCR Fusion Gene. NCI Thesaurus. Code C99683.

A fusion gene that results from a chromosomal translocation $t(9 ; 22)(q 34 ; q 11)$ that fuses the extreme 5' portion of the ABL1 to part of the 3' portion of the BCR gene. This rearrangement is associated with chronic myelogenous leukemia, acute lymphoblastic leukemia and acute myeloid leukemia. 